\title{
Antimalarial drug discovery: targeting the hypnozoite for new radical curative agent
}

\author{
Bryan Yeung \\ From Challenges in malaria research \\ Basel, Switzerland. 10-12 October 2012
}

Plasmodium vivax malaria remains a significant health burden in endemic areas like South East Asia, Central and South America. P. vivax infections are characterized by relapses of malaria caused by persistent liver stages of the parasite (hypnozoites) which are not present in $P$. falciparum infections. Currently, the only approved treatment option for the radical cure of P. vivax malaria is the 8 -aminoquinoline, primaquine. However the long treatment course (two weeks) and severe side effects (hemolytic anemia in G6PD-deficeint patients) highlights the need for new chemical classes of drugs.

Currently the discovery of new anti-hypnozoite drugs is limited to testing in the $P$. cynomolgi rhesus monkey model. However recently developed assays that allow for the testing of new chemical entities on the parasite liverstages (schizonts) and sexual stages (gametocytes) could be leveraged to identify dual acting compounds with potental anti-hypnozoite activity. In addition, compounds which target more than one stage in the Plasmodium lifecycle would be highly valued and compliment the current arsenal of antimalarial drugs.

Published: 15 October 2012

Submit your next manuscript to BioMed Central and take full advantage of:

- Convenient online submission

- Thorough peer review

- No space constraints or color figure charges

- Immediate publication on acceptance

- Inclusion in PubMed, CAS, Scopus and Google Scholar

- Research which is freely available for redistribution 